\title{
The role of Soviet modernism objects in the formation of Rostov-on-Don silhouette along the Don River embankment
}

\author{
Anna Ivanova-Ilyicheva and Nadezhda Sidorenko* \\ Southern Federal University, Academy of Architecture and Arts, 344000, Rostov-on-Don, Russia
}

\begin{abstract}
The active use of the landscape features in urban areas for the architectural environment formation has become a topical method of urban planning in the USSR. Developed in the late 1960s the new master plans for the large cities in the country primarily emphasized the existing natural features. Rostov-on-Don was no exception. Here, the main principle of urban planning in the early 1970s began to focus on the urban development disclosure in the direction of the Don River, which continued the tradition of the general plan of the 1930s and the post-war reconstruction concept. It was planned to demolish the dilapidated and warehouse buildings that had built up the slope descending from the city to the river, as well as to preserve the valuable historical sites and create the new structures in the form of modernism. The article analyzes the principles of the formation of silhouette buildings in Rostov-on-Don from the central embankment side. In the course of field studies and photographs, a panorama of the central embankment of the 1970-1980s city was compiled, the planning of the panorama, spatial landmarks and axes were revealed. The objects of modernism participating in the silhouette creation are analyzed as well as their role is determined depending on their location relative to the river (on the embankment, on the slope, in the central building). Unrealized structures of the 1970s, revealing the general principles of building spatial landmarks, have been studied.
\end{abstract}

\section{Introduction}

The need to provide the population with healthy conditions that meet the standards of fullfledged life of a modern city dweller determined the primary task for the architects of the 1960s - 1980s. "Sun, greenery, space" back in 1933 were proclaimed the main elements of the urban environment improvement according to the manifesto of the "Athenian Charter", the text of which was compiled by the universally recognized world master of modernism Le Corbusier [1].

In the late 1960s and 1970s in the Soviet Union, master plans were developed for a number of cities. New cities were created - satellite cities; cities in areas suitable for the industrial activities' organization. The most important element in the formation of all master plans was the natural aspect. The normative documents of the Soviet Union noted

\footnotetext{
*Corresponding author: ya.sinaro@yandex.ru
} 
that "the planning and development of populated areas should ensure the creation of an expressive volumetric-spatial composition of the entire populated area and its individual parts. In the architectural appearance of a populated place, one should take into account the importance of this place, natural features and the surrounding landscape" [2]. In 1971, the New General Plan of Moscow was approved, which assumed the division of the city territory into eight relatively autonomous residential formations, separated by large forestpark zones, where recreation sites for Muscovites were located. The general plan of Leningrad in 1966 provided for the city development on the historical center ensemble basis, the most important component of which are the water canal system embankments, palace gardens and parks. The master plan of Togliatti developed in 1968 was based on a system of enlarged planning modules, commensurate with the surrounding landscape. Recreational zones played a leading role in the development of master plans for Kiev in 1966, Chelyabinsk in 1967, Dnepropetrovsk in 1967 and many other cities of the former republics of the Soviet Union, including Rostov-on-Don $[3,4]$.

The Don River was the most important factor in the city formation. Before the revolution, Rostov-on-Don was built up in such a way that a beautiful high-water river was cut off from the city by warehouses, pier devices and a railway, and most of the buildings were turned by courtyard facades and outbuildings to the Don [5]. Already after the revolution and even more intensively after the end of the Great Patriotic War, the work, the purpose of which was to turn the city towards the Don, was carried out, but by the early 1960s from the side of the Rostov-on-Don river, there was still a rather faceless figure. Therefore, the main feature of the new layout of the center in the 1960-1970s became a multifaceted deep disclosure of buildings towards the Don with access to the embankment of several green boulevards [6]. The objects of research in the article are the buildings of modernism participating in the formation of the silhouette of the central embankment of Rostov-on-Don. The purpose of the work is to determine the role of these objects in creating the main panorama of the city.

\section{Methods}

The archival sources, scientific journalistic and graphic materials on the research topic were studied. Field surveys and a multidimensional analysis of structures from the $1960 \mathrm{~s}-1980 \mathrm{~s}$, which form the silhouette of the central embankment in Rostov-on-Don, have been carried out.

\section{Results}

Three plans can be distinguished in the formation of the city silhouette along the Don River. This is determined by the steep relief of the right bank, thanks to which the buildings of Rostov-on-Don rise above the river. The foreground is the lower terrace of the embankment, which runs along the coastal line of the Don. The second plan - the objects located on the upper terrace of the slope, arranged along the streets of Donskoy and Sedov. The third plan is the background structures located in the area of the central Engels street, but viewed from the banks of the Don due to the rise above the surroundings (Fig. 1). 

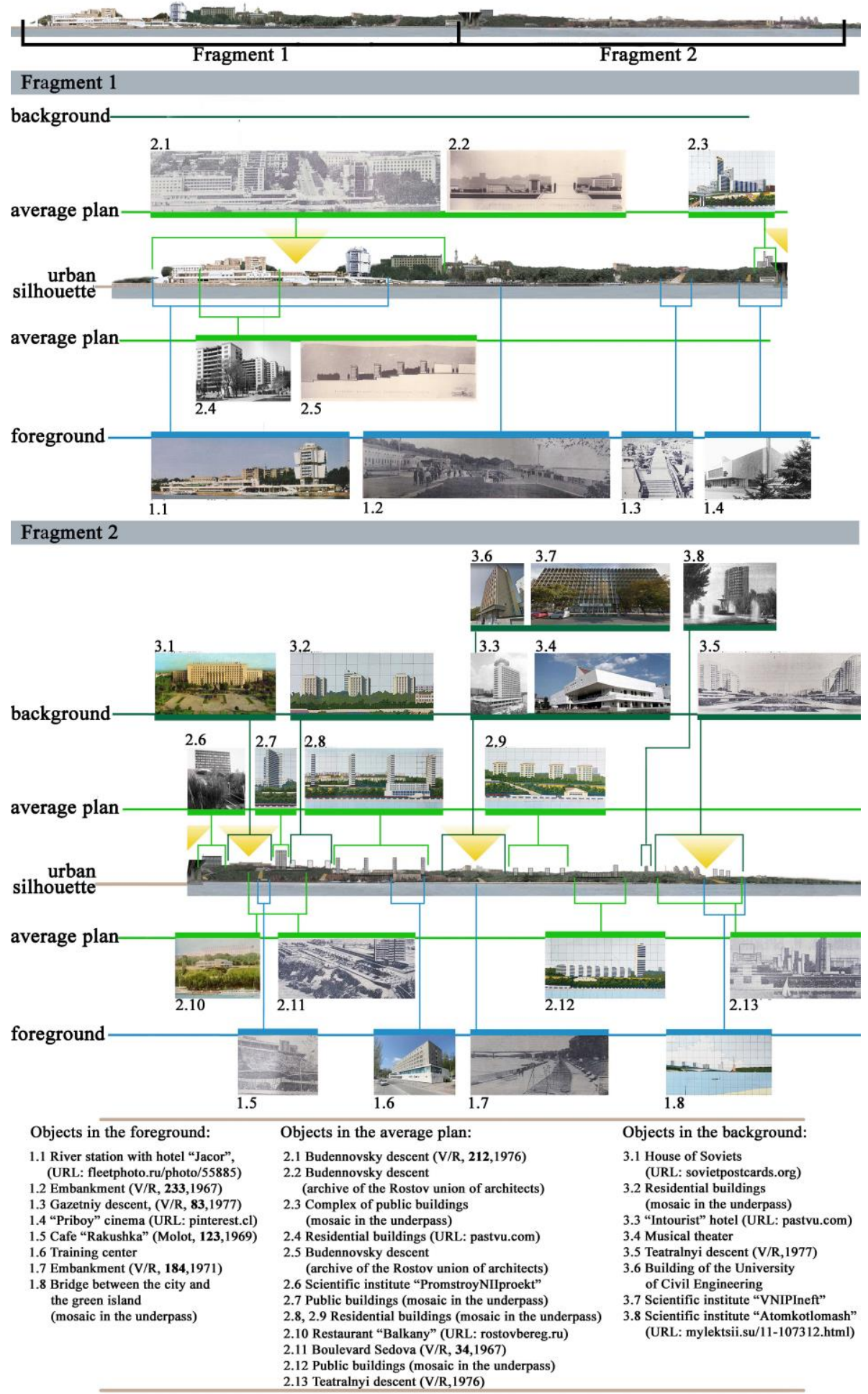

Fig. 1. Analytical scheme of the central embankment panorama of Rostov-on-Don in the 1970s. 
One of the most successful solutions for turning the city towards the river was the organization of visual connections between the embankment and the central building. These prospects were supposed to be created along the main meridian planning axes Budennovsky, Voroshilovsky and Teatralny avenues. For this, it became necessary to clear the area between Beregovaya and Engels streets from the unnecessary structures that have no value. The slope between the two terraces of the embankment from Budennovsky Avenue to Kirovsky Descent was freed from warehouse and low-rise buildings and turned into a continuous green strip. Residential quarters above Sedov Street were moved apart in such a way as to form corridors opening a view of large buildings, the architectural dominants of the city - the House of Soviets, the theater named after V. M. Gorky, a group of objects of the cultural and educational center on Engels Street [7]. These buildings, together with the bell tower of the cathedral, towering over the city, created the accents of the third plan of the city panorama.

The main descents to the embankment along Budennovsky, Voroshilovsky and Teatralniy avenues were recorded using the flanking high-altitude dominants located on the second tier of the slope. The grandiose-scale esplanades connecting Beregovaya Street and Teatralnaya Square were supported by tower residential buildings [8]. They were designed in groups of three volumes on both sides of the descent, developing in cascades from Nizhnebulvarnaya Street upwards, enhancing the depth of space and emphasizing the importance of the compositional core of the perspective - the Theater. M. Gorky. The houses were sold only on the western side. It should be noted that an architectural competition was organized in 1971 to solve the Theater Descent. The presented works differed in various approaches, but in all variants the interaction with the landscape and the natural component came to the fore. In the Burevestnik project, public and residential buildings are cascaded on the slope, decreasing in number of storeys as they descend. In the work "Five matches" it is proposed to create an extensive park along the axis of the theater, in the greenery of which there will be residential areas, where houses are located on reinforced concrete overpasses. The authors of "Noctilucent Cloud" divided the descent into three zones (front, green and embankment), connected by stairs and ramps; in the upper part, it is proposed to create the houses of smooth shapes, and move traffic along Engels Street under the ground. Similar ideas with the creation of green arrays were demonstrated in the works "Green Wedge" and "Blue Square". The Scarlet Sails project involved the construction of tower houses and the connection of the slope with the Green Island and the left bank of the Don by means of a two-tiered bridge, in which one of the tiers is intended for pedestrians, and the other for cars. In the works "Trefoil" and "1749" instead of the bridge, the creation of an aerial cableway is provided [9].

The props of the Voroshilovsky bridge at the entrance to the city were located along Donskaya Street (second plan): on the east side - an eleven-story building "Promstroy NII proekt"; from the west - a complex of high-rise buildings, which in the end was not implemented. Unlike Teatralny Descent, where the dilapidated building of the slope and the solemnity of the space allowed using a widespread technique (a number of tower volumes), it was decided to emphasize the perspective of Karl Marx Avenue with single structures. This is determined by the predominant direction of the bridge straight line linking the city center with the left bank of the Don river. In addition, historical mid-rise buildings began immediately behind the flanking complex.

In an interesting way, the prospect of Budennovsky Avenue is fixed. On the western side of the descent, there are traditionally cascades of residential buildings - four ten-storey tower volumes, implemented according to a unique project, the author of which is the "Rostovgrazhdanproekt" architect D. A. Safonov. On the contrary, there is a nine-storey building located in the depths of the plot to create a landscaped terrace and oriented along the main axis for almost the entire length of the block. Thus, he emphasized the length of 
the avenue, and the twelve-story hotel became the vertical dominant on the eastern side. «Anchor», a part of the river station and shifted to the right relative to the central line of Budennovsky. This complex was designed by metropolitan architects [10]. To the west of the tower houses and to the east of the hotel there are administrative buildings oriented along the Don and research institute fisheries, enhancing the effect of the visual corridor. The two-storey building of the river station itself, located directly on the embankment, blocks the view of the highway with busy traffic. This decision is quite justified, since Budennovsky Avenue does not have a central compositional core, like the Teatralny Descent, and does not communicate with the left bank like Voroshilovsky Bridge.

Architectural dominants of the third plan, as well as the main avenues, were emphasized by the buildings of the second level. House of Soviets flanked the building "Promstroy NII proekt" and the high-rise volume of the administrative center, projected in the area of the observation deck on Sedova Street. The group of cultural and educational structures was supposed to be compositionally fixed with the help of high-rise nine- and sixteen-story tower buildings, located in groups of four objects along the embankment on different sides of the visual corridor. A similar technique appeared at the level of the third plan solution, filling in the spaces between the main elements of the panorama. On the site between the cultural and educational complex and the theater. M. Gorky, an administrative center with a tower volume was designed. To the east, the silhouette of a seventeen-story "Atomkotlomash". The spatial "emptiness" was filled with high-rise accents.

The river station with the hotel has become the most striking element of the first plan of the central embankment, the calm vertical profile of which is mainly formed by the elements of landscaping (cafe awnings, gazebos). There are also some preserved low-rise historical buildings, among which there are examples of reconstruction of the period of Soviet modernism (stereo cinema «Priboy»). The abundant landscaping of the embankment was supposed to hide the facade of a typical 1970s educational center building located close to Beregovaya Street. So, the cubic volume became a background element that did not interfere with the general perception.

\section{Conclusion}

Thus, the Don river right bank relief made it possible to form an expressive silhouette of the city, visible from the southern approaches to it and from the left bank of the Don river, with the help of the construction of new objects and adjustments to the existing buildings. The composition of this part is designed in such a way that the development of cascades of buildings and terraces of interconnected boulevards, squares, viewing platforms descended to the embankment, organizing with it a single volume-spatial ensemble. The role of the Soviet modernism objects was to create high-rise dominants and the organization of spatial visual corridors connecting the embankment with the central part of the city.

\section{References}

1. T.G. Maklakova, 20th century architecture. Modern architecture (Publishing House of the Association of Civil Engineering Universities, Moscow, 2001).

2. SNiP II-K.2-62. Planning and development of populated areas (Publishing house of literature on construction, Moscow, 1967).

3. N.P. Bylinkin, A.M. Zhuravleva, A.M. Shishkina, Modern Soviet architecture 1955 1980: Textbook for universities (Stroyizdat, Moscow, 1985).

4. A.M. Ivanova-Ilyicheva, N.R. Sidorenko, Bulletin of BSTU named after V.G. Shukhov 6, 47-55 (2020). 
5. Ya.A. Rebin, Molot 6 (14056), 3 (1969).

6. V. Selivanov, Vecherniy Rostov 305 (5640), 2 (1976).

7. Ya.A. Rebine, Rostov steps into the future (Rostov Book Publishing House, Rostovon-Don, 1968).

8. L. Evchenko, Evening Rostov 300 (6245), 3 (1978).

9. V. Ktorov, Evening Rostov 133 (3961), 3 (1971).

10. Ya.A. Rebin, Hammer 224 (15491), 2 (1973). 